\title{
Marine Ecosystem Science on an Intertwined Planet
}

\author{
Henrik Österblom, ${ }^{1 *}$ Beatrice I. Crona, ${ }^{1,2}$ Carl Folke, ${ }^{1,2,3}$ Magnus Nyström, ${ }^{1}$ \\ and Max Troell ${ }^{1,3}$
}

\begin{abstract}
${ }^{1}$ Stockholm Resilience Centre, Stockholm University, 10691 Stockholm, Sweden; ${ }^{2}$ Global Economic Dynamics and the Biosphere, Royal Swedish Academy of Sciences, P.O. Box 50005, 10405 Stockholm, Sweden; ${ }^{3}$ Beijer Institute for Ecological Economics, Royal Swedish Academy of Sciences, P.O. Box 50005, 10405 Stockholm, Sweden
\end{abstract}

\begin{abstract}
Marine ecosystem science has developed since the 1940s, when humans obtained the ability to spend substantial time underneath the surface of the ocean. Since then, and drawing on several decades of scientific advances, a number of exciting research frontiers have emerged. We find: Understanding interacting drivers of change, Identifying thresholds in ecosystems, and Investigating social-ecological dynamics to represent particularly interesting frontiers, which we speculate will soon emerge as new mainstreams in marine ecosystem science. However, increasing human impacts on ecosystems everywhere and a new level of global connectivity are shifting the context for studying, understanding, and managing marine ecosystems. As a con-
\end{abstract}

sequence, we argue that ecosystem scientists today also need to address a number of critical challenges and devote new energy and expertise to Modeling the Anthropocene, Operationalizing resilience, and Understanding social-ecological dynamics across scales. This new deep dive into unknown waters requires a number of strategies to be successful. We suggest that marine ecosystem scientists need to actively: Prepare for the unexpected, cross boundaries, and understand our cognitive limitations to further develop the exciting field of marine ecosystem science.

Key words: Resilience; social-ecological system; regime shift; globalization; anthropocene; ecology.

\section{DOWN BY THE WATER}

The aqualung, introduced in the late 1940s, opened up new possibilities to explore marine life. Research on interactions of marine organisms with each other and the surrounding environment intensified, and marine ecosystem science was born. Since then, molecular tools, remote sensing techniques, advanced computer models, and statistical methods

\footnotetext{
Received 30 March 2016; accepted 17 May 2016; published online 14 June 2016

Author contribution All authors contributed to the development of the original idea. HÖ led the writing of the paper and all other authors contributed equally to writing. Authors 2-5 are listed in alphabetical order.

*Corresponding author; e-mail: henrik.osterblom@su.se
}

have provided new ways to investigate marine ecosystems and, during the last few decades, the understanding of marine ecosystems has increased exponentially (Paine 1969; Jackson and others 2001; Howarth and Marino 2006).

It is now clear that ecosystem dynamics and earth system processes are fundamentally shaped by human actions (Turner and others 1990; Rockström and others 2009). This new context, often referred to as a new geological era (the Anthropocene) is characterized by unprecedented connectivity between ecological and social domains, from local to global scales (Adger and others 2009; Walker and others 2009) and manifested by increasing speed in terms of extraction and flow of resources, activities, 
ideas, and information across geographic and jurisdictional scales (Folke and others 2011; Brondizio and others 2016). Such intertwined social and ecological processes also shape marine ecosystems. Hence, marine ecosystems are not only influenced by human actions, but rather, humans are increasingly becoming embedded parts of the dynamics and behavior of marine ecosystems (Fulton and others 2011; Glavovic and others 2015) in what we refer to as social-ecological systems (Berkes and Folke 1998). This new reality necessitates a re-evaluation of how marine ecosystems are perceived and studied as well as managed and governed.

Most, if not all, marine ecosystems are in some way connected to the globalized economy and often impacted by human activities at regional or global scales (Hoegh-Guldberg and Bruno 2010; Crona and others 2015; Gattuso and others 2015). Hence, human activities previously not considered to be of immediate relevance to marine scientists are now playing a most central role in shaping marine ecosystem dynamics worldwide (Norström and others 2016). For example, urbanization and consumption patterns influence prices, incentives, and activities in the seafood, agricultural, transport, tourism, and energy sectors, ultimately affecting resource extraction patterns and release of toxins, heavy metals, organic particles, and nutrients, or leading to the destruction of marine habitats (Figure 1). The new, and increasingly diverse ways in which actors at various scales, and in different sectors, interact with marine ecosystems is also challenging the capacity of institutions set up to govern the marine environment to adapt to rapid and non-linear social, economic, and technical change (Galaz and others 2016; Merrie and others 2014). Marine ecosystem science is confronted with a changing, and increasingly interconnected turbulent world.

The social-ecological connectivity of marine ecosystems across geographic regions and between sectors is widespread (Deutsch and others 2007; Homer-Dixon and others 2015) with 'teleconnected' social-ecological dynamics across previously unconnected systems (Adger and others 2009; Liu and others 2015). This rising connectivity increases the likelihood of tipping points by reducing the 'modularity' of the system (Scheffer and others 2012) and as marine and terrestrial food production systems are increasingly intertwined, consequences for global food security, and resilience is largely unknown (Merino and others 2012; Troell and others 2014; Béné and others 2015). Fishing technologies and practice, mediated by political interests and globally operating actors, can spread rapidly across the planet (Norse and others 2012; Pauly and others 2013; Österblom and Folke 2015), some- times at a speed and scale even resembling pathological disease dynamics (Eriksson and others 2015). Such novel cross-scale interactions represent new challenges for understanding marine ecosystem dynamics but also open new opportunities for stewardship of marine ecosystems, exemplified by global certification schemes (Jacquet and others 2010) and by actors in key positions in seafood value chains (Österblom and others 2015).

\section{LitTle Fish: Three EMERging Mainstreams of Marine Ecosystem SCIENCE}

Small fish are easier to catch than big fish. A decade of summer holiday gillnetting in the Baltic Sea may yield one individual cod Gadus morhua, whereas springtime handlining may yield hundreds of individual herring Clupea harengus. Anyone with proper equipment and basic knowledge can catch herring. However, smoking it to the perfect flavor and getting the right golden shine on the skin is proof of skills. Consuming this delicacy in perfect Swedish summer weather requires a bit of pure luck.

Here, we present three current research frontiers that represent emerging mainstream areas of marine ecosystem science. In the context of a globally intertwined planet, they exemplify 'little fish'easy to identify, requiring skills to refine, but not necessarily capturing key future challenges of marine ecosystem science.

\section{Understanding Interacting Drivers of Change}

An increasing understanding of complex and interacting changes in marine ecosystems has led scientists to move from studying species interactions towards focusing on non-linear interactions (Cury and others 2011), interacting drivers of change (Halpern and others 2008), or cascading effects in complex food webs (Frank and others 2005). Research on how climate variability and change, including ocean acidification, fundamentally influence species phenology, abundance, and distribution is gaining attention (Hoegh-Guldberg and Bruno 2010; Gattuso and others 2015) as well as how humans influence marine ecosystem dynamics through removal of predators and prey, altering of habitats, or by adding nutrients, 


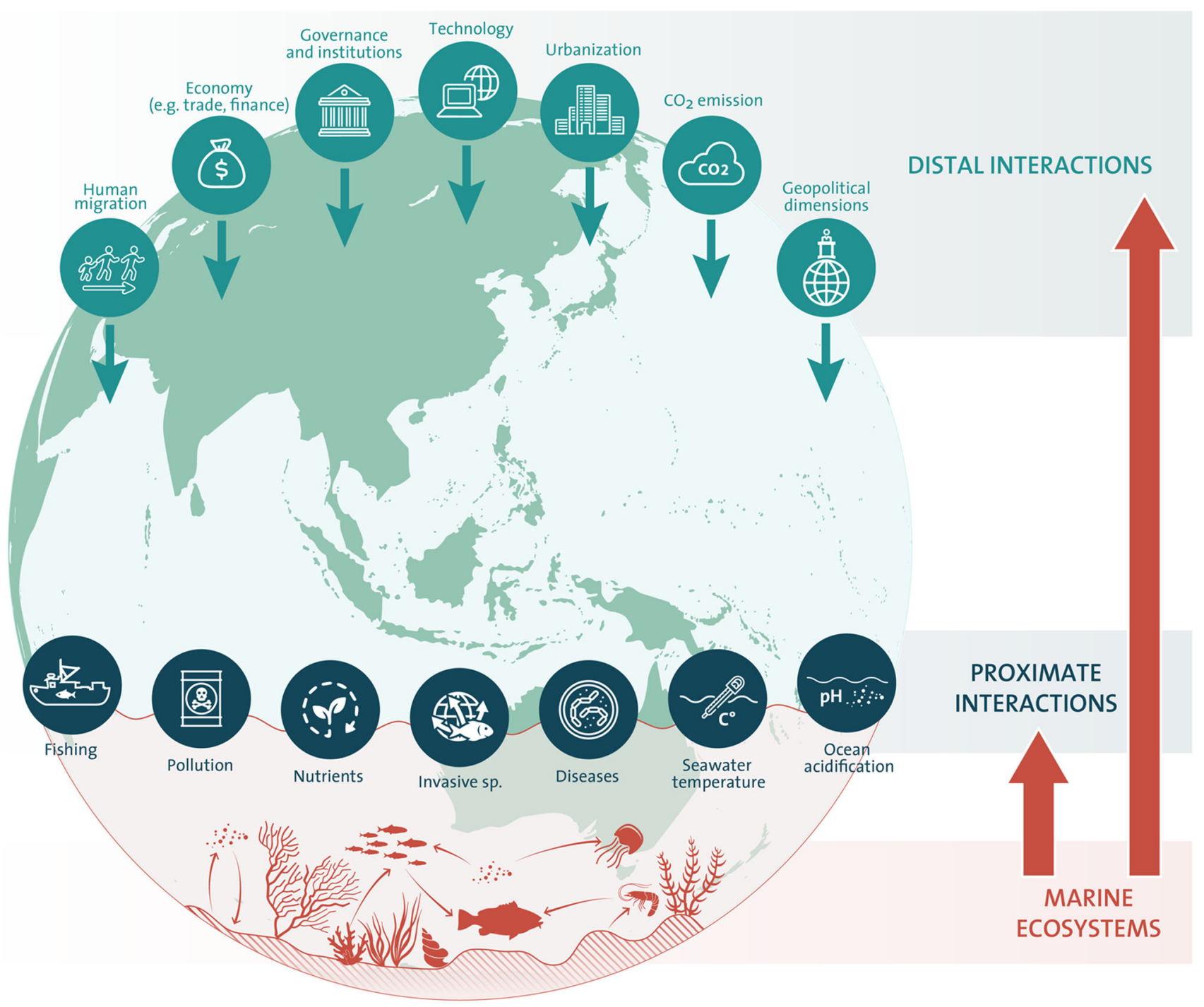

Figure 1. Marine ecosystem science on an intertwined planet. Changes in marine ecosystem dynamics are influenced by socioeconomic activities (for example, fishing, pollution) and human-induced biophysical change (for example, temperature, ocean acidification) and can interact and severely impact marine ecosystem dynamics and the ecosystem services they generate to society. Understanding these direct-or proximate-interactions is an important step towards sustainable use of marine ecosystems. However, proximate interactions are embedded in a much broader socioeconomic context where, for example, economy through trade and finance, human migration and technological advances, operate and interact at a global scale, influencing proximate relationships. These indirect—or distal—interactions add dimensionality and complexity to the global marine social-ecological system

toxins, and so on (Jackson and others 2001; Folke and others 2004; Eriksen and others 2014). Corresponding modeling efforts have moved from carbon budgets to models that incorporate complex ecological, biophysical, and chemical changes (Cheung and others 2009; Keeling and others 2010).

\section{Identifying Thresholds in Ecosystems}

Observational, experimental, and modeling studies have shown that many marine ecosystems are characterized by non-linear dynamics and thresholds (or tipping points), which if surpassed may cause systems to shift into alternative states or regimes (Hare and Mantua 2000; Scheffer and others 2001; Rocha and others 2015). The likelihood of such shifts increases with human actions that cause loss of resilience (Folke and others 2004; Österblom and Folke 2015). Because shifts to alternative states may imply significant losses of ecosystem services, much effort has been directed towards a better understanding of the location of tipping points 
(Biggs and others 2009), which can support ecosystem managers' ambitions to stay away from unexpected (unwanted) change or address feedback mechanisms that maintain ecosystems in degraded states and try to break them (Nyström and others 2012). Novel models are being developed to identify indicators that may signal approaching thresholds (Dakos and others 2015).

\section{Investigating Social-Ecological Dynamics}

Approaches to study marine ecosystems as components of truly integrated marine social-ecological systems (Berkes and Folke 1998; Perry and others 2011) range from research on how markets and incentives shape marine food webs (Ferrol-Schulte and others 2014) to the role of marine ecosystems for coastal livelihoods (Allison and Horemans 2006) and advanced social-ecological modeling (Lade and others 2015). Applications of the socialecological lens to marine systems also includes work on adaptive responses to restore and improve marine ecosystems, such as increases in protected areas and novel frameworks, tools, and dynamic approaches for managing fisheries (Degnbol and McCay 2006; Branch 2009; Dunn and others 2016). Studies investigating how actors organize to improve ecosystem stewardship at various interacting geographical levels have grown substantially (Young and others 2007; Gelcich and others 2010) and novel methods are enabling an understanding of generic features of marine social-ecological systems across cultural, economic, and political contexts (Gutierrez and others 2011; Cinner and others 2012; Bundy and others 2015).

\section{Big Fish: Moving Beyond Existing FronTIERS}

\begin{abstract}
Big fish are generally more difficult to catch than small fish. Catching big fish can be intimidating, and killing and gutting them is not always fun. But ultimately it is a much bigger meal, and the reward is greater.
\end{abstract}

The new global context is resulting in a situation where marine ecosystem scientists are challenged to move beyond existing research frontiers. Studying more of the same easily leads to confirmation bias and limits the ability to think creatively about critical factors of marine ecosystem dynamics of an increasingly connected and unpredictable so- cial-ecological future. Marine scientists should therefore be encouraged to venture out into the largely unexplored-to set their eyes on some 'big fish'-three of which are outlined below.

\section{Modeling the Anthropocene}

Existing modeling efforts are already moving from species interactions, to fisheries-human interactions and ecosystem-social interactions (Hughes and others 2005). Important next steps will be to understand and incorporate the mechanisms behind the traditional "drivers of change" studied (Figure 1). What are the mechanisms driving change in industries and activities shaping marine ecosystems? For instance, how does urbanization or intensified land use lead to runoff and sedimentation changes, or disease spread in coastal marine ecosystems? How does aquaculture development reduce pressure on marine habitats and food webs, or how does conservation of species in one area, result in outsourcing of problems and ecosystem impacts elsewhere? Existing models and scenarios critically need to incorporate methods, theories, and approaches from adjoining disciplines to further understanding of marine systems in the new global context. Incorporating non-linear change, surprise, and cascading social-ecological dynamics represent additional key challenges.

\section{Operationalizing Resilience}

The concept of resilience, gaining attention in science, policy, and practice, is closely associated with research on thresholds and alternative states (Holling 1973; Scheffer and others 2001). Loss of resilience increases the likelihood of approaching thresholds. Progress has been made to understand and quantify marine ecosystem resilience (Nyström and others 2008), but understanding resilience of marine social-ecological systems remains a critical challenge. Work on general principles for building resilience in social-ecological systems (Biggs and others 2009) has raised the question of relevant indicators (Quinlan and others 2015). For socialecological systems, resilience thinking incorporates interactions between slow and fast variables contributing to general and specified resilience (Folke and others 2010). What factors determine the adaptive capacity of species, ecosystems, and linked social-ecological systems and how can marine social-ecological systems build general resilience to deal with the new climate reality, the new globalized economy, and a truly intertwined social-ecological planet? 


\section{Understanding Social-Ecological Dynamics Across Scales}

An integrated understanding of social-ecological dynamics can inform the scientific understanding of how human communities, nations, and regions adapt and respond to social-ecological change and how they may transform towards ecosystem-based approaches to marine management (Berkes 2012). Case studies of adaptive governance and system transformations have illustrated how global connectivity facilitates the rapid spread of ideas and governance approaches across regions, with possible global implications for how institutions at diverse geographical scales interact with ecosystems (Schultz and others 2015). These processes are often studied "from the outside" or in a historical perspective. Moving this research frontier forward may involve work where academics become embedded in change processes that are deliberately designed as experiments. Such strategically guided change processes would allow for systematic monitoring and evaluation to harvest new insights on adaptation and transformations in marine social-ecological systems. It needs to be stressed that an increased focus on enabling transformation does not in any way reduce the importance of an in depth understanding of marine ecosystem dynamics, but rather adds important components in order to investigate and understand social-ecological dynamics across scales.

\section{Swimming in the Water: Scientific Strategies for Staying Ahead of the GAME}

Catching both small and big fish requires a stronger link between empirical research and theory, between interconnected dynamics of local and global scales, and between modeling and experimentation, but also incorporation of theories, models, data, and analytical methods from diverse disciplines. The latter will hopefully enable us to engage with questions that currently seem impossible to answer due to existing limitations in data or approaches. Below, we outline three broad strategies for scientists interested in developing capacity to move current research frontiers, big or small, forward.

Substantial social-ecological surprise and shocks are becoming the global norm-from climate change induced flooding, or financial crises impacting on food prices, to armed conflict and pervasive migration. Preparing for the unexpected is therefore a critical research strategy. Consequently, scientists, as well as policy makers and practitioners, need to be aware of, and prepare for, unexpected events that may originate outside traditional marine ecosystem science, and make this "unknown" part of the wider research and policy agenda.

The speed, scale, and connectivity outlined above requires an increased collaboration across disciplinary boundaries with "marine scientists" working in synergy with researchers from seemingly distant research areas such as nanotechnology, genetic engineering, artificial intelligence, gender and equity, or business administration and finance. Such collaboration can help identify novel ways to understand and govern marine ecosystems.

Finally, we must understand our cognitive limitations - the priorities described above have primarily emerged from North American, European, and Australian scientific communities-clearly not a representative sample of knowledge systems, world views, priorities, and attitudes. New scientific leadership may fundamentally change these outlined priorities.

There are dangers associated with doing something uncomfortable, but also rewards. Jumping in at the deep end of the pool is fun the first time you try it, but quickly becomes normal as you learn how to swim. Jumping into the water from ten meters above never gets old. It is completely terrifying every time: a short period of weightlessness and panic, followed by a sudden impact. It is exciting and not completely safe. We argue that the concept of the Anthropocene requires marine scientists to move outside traditional comfort zones - to take a big dive, a deep swim, and go for some big fish!

\section{ACKNOWLEDGEMENTS}

PJ Harveys' song "Down By The Water" containing the chorus "Little fish, big fish, swimming in the water" was published in 1995. PJ started out as punk but is becoming increasingly mainstream. But she has never compromised with quality or integrity. This manuscript is an encouragement to marine ecosystem scientists to continue to break new ground, develop novel research frontiers, and help convert the crazy and far out into the next mainstream. We appreciate financial support from Mistra, the Baltic Ecosystem Adaptive Manage- 
ment (BEAM) program, the Nippon Foundation, the Erling Persson Family Foundation and the Kjell and Märta Beijer Foundation. Drs S. Carpenter, M. Turner, and V. Galaz provided constructive comments on earlier drafts.

\section{OPEN ACCESS}

This article is distributed under the terms of the Creative Commons Attribution 4.0 International License (http://creativecommons.org/licenses/by/ 4.0/), which permits unrestricted use, distribution, and reproduction in any medium, provided you give appropriate credit to the original author(s) and the source, provide a link to the Creative Commons license, and indicate if changes were made.

\section{REFERENCES}

Adger WN, Hallie E, Winkels A. 2009. Nested and teleconnected vulnerabilities to environmental change. Front Ecol Environ 7:150-7.

Allison EH, Horemans B. 2006. Putting the principles of the sustainable livelihoods approach into fisheries development policy and practice. Marine Policy 30:757-66.

Béné C, Barange M, Subasinghe R, Pinstrup-Andersen P, Merino G, Hemre G-I, Williams M. 2015. Feeding 9 billion by 2050—putting fish back on the menu. Food Secur 7:261-74.

Berkes F. 2012. Implementing ecosystem-based management: evolution or revolution? Fish Fish 13:465-76.

Berkes F, Folke C. 1998. Linking social and ecological systems: management practices and social mechanisms for building resilience. Cambridge: Cambridge University Press.

Biggs R, Carpenter SR, Brock WA. 2009. Turning back from the brink: detecting an impending regime shift in time to avert it. Proc Natl Acad Sci USA 106:826-31.

Branch TA. 2009. How do individual transferable quotas affect marine ecosystems? Fish Fish 10:39-57.

Brondizio ES, O'Brien $\mathrm{K}$, Bai $\mathrm{X}$, Biermann $\mathrm{F}$, Steffen $\mathrm{W}$, Berkhout F, Cudennec C, Lemos MC, Wolfe A, Palma-Oliveira J, Chen C-TA. 2016. Re-conceptualizing the Anthropocene: A call for collaboration. Global Environmental Change (in press).

Bundy A, Chuenpagdee R, Cooley SR, Defeo O, Glaeser B, Guillotreau P, Isaacs M, Mitsutaku M, Perry RI. 2015. A decision support tool for response to global change in marine systems: the IMBER-ADApT Framework. Fish Fish. Early View.

Cheung WWL, Lam VWY, Sarmiento JL, Kearney K, Watson R, Pauly D. 2009. Projecting global marine biodiversity impacts under climate change scenarios. Fish Fish 10:235-51.

Cinner JE, McClanahan TR, MacNeil MA, Graham NAJ, Daw TM, Mukminin A, Feary DA, Rabearisoa AL, Wamukota A, Jiddawi N, Campbell SJ, Baird AH, Januchowski-Hartley FA, Hamed S, Lahari R, Morove T, Kuange J. 2012. Comanagement of coral reef social-ecological systems. Proc Natl Acad Sci 109:5219-22.

Crona BI, Daw TM, Swartz W, Norström AV, Nyström M, Thyresson M, Folke C, Hentati-Sundberg J, Österblom H, Deutsch L, Troell M. 2015. Masked, diluted and drowned out: how global seafood trade weakens signals from marine ecosystems. Fish Fish Early View.

Cury PM, Boyd IL, Bonhommeau S, Anker-Nilssen T, Crawford RJM, Furness RW, Mills JA, Murphy EJ, Österblom H, Paleczny M, Piatt JF, Roux J-P, Shannon L, Sydeman WJ. 2011. Global seabird response to forage fish depletion-one-third for the birds. Science 334:1703-6.

Dakos V, Carpenter SR, van Nes EH, Scheffer M. 2015. Resilience indicators: prospects and limitations for early warnings of regime shifts. Philos Trans $\mathrm{R}$ Soc Lond B Biol Sci 370:20130263.

Degnbol P, McCay BJ. 2006. Unintended and perverse consequences of ignoring linkages in fisheries systems. ICES J Mar Sci 64:793-7.

Deutsch L, Gräslund S, Folke C, Troell M, Huitric M, Kautsky N, Lebel L. 2007. Feeding aquaculture growth through globalization: exploitation of marine ecosystems for fishmeal. Glob Environ Change 17:238-49.

Dunn DC, Maxwell SM, Boustany AM, Halpin PN. 2016. Dynamic ocean management increases the efficiency and efficacy of fisheries management. Proc Natl Acad Sci 113: 668-73.

Eriksen M, Lebreton LCM, Carson HS, Thiel M, Moore CJ, Borerro JC, Galgani F, Ryan PG, Reisser J. 2014. Plastic pollution in the world's oceans: more than 5 trillion plastic pieces weighing over 250,000 tons afloat at Sea. PLoS ONE 9:e111913.

Eriksson H, Österblom H, Crona B, Troell M, Andrew N, Wilen J, Folke C. 2015. Contagious exploitation of marine resources. Front Ecol Environ 13:435-40.

Ferrol-Schulte D, Ferse SCA, Glaser M. 2014. Patron-client relationships, livelihoods and natural resource management in tropical coastal communities. Ocean Coast Manag 100:6373.

Folke C, Carpenter S, Walker B, Scheffer M, Elmqvist T, Gunderson L, Holling CS. 2004. Regime shifts, resilience, and biodiversity in ecosystem management. Annu Rev Ecol Evol Syst 35:557-81.

Folke C, Carpenter SR, Walker B, Scheffer M, Chapin T, Rockström J. 2010. Resilience thinking: integrating resilience, adaptability and transformability. Ecol Soc 15:20.

Folke C, Jansson $\AA$, Rockström J, Olsson P, Carpenter SR, Chapin FSIII, Crépin AS, Daily G, Danell K, Ebbesson J, Elmqvist T, Galaz V, Moberg F, Nilsson M, Österblom H, Ostrom E, Persson $\AA$, Peterson G, Polasky S, Steffen W, Walker B, Westley F. 2011. Reconnecting to the biosphere. Ambio 40:719-38.

Frank KT, Petrie B, Choi JS, Leggett WC. 2005. Ecology: trophic cascades in a formerly cod-dominated ecosystem. Science 308:1621-3.

Fulton EA, Smith ADM, Smith DC, van Putten IE. 2011. Human behaviour: the key source of uncertainty in fisheries management. Fish Fish 12:2-17.

Galaz V, Österblom H, Bodin Ö, Crona B. 2016. Global networks and global change-induced tipping points. Int Environ Agreem Polit Law Econ 16:189-221.

Gattuso J-P, Magnan A, Billé R, Cheung WWL, Howes EL, Joos F, Allemand D, Bopp L, Cooley SR, Eakin CM, Hoegh-Guldberg O, Kelly RP, Pörtner H-O, Rogers AD, Baxter JM, Laffoley D, Osborn D, Rankovic A, Rochette J, Sumaila UR, Treyer S, Turley C. 2015. Contrasting futures for ocean and society from different anthropogenic $\mathrm{CO}_{2}$ emissions scenarios. Science 349 . 
Gelcich S, Hughes TP, Olsson P, Folke C, Defeo O, Fernández M, Foale S, Gunderson LH, Rodríguez-Sickert C, Scheffer M, Steneck RS, Castilla JC. 2010. Navigating transformations in governance of Chilean marine coastal resources. Proc Natl Acad Sci USA 107:16794-9.

Glavovic BC, Limburg K, Liu KK, Emeis KC, Thomas H, Kremer H, Avril B, Zhang J, Mulholland MR, Glaser M, Swaney DP. 2015. Living on the Margin in the Anthropocene: engagement arenas for sustainability research and action at the ocean-land interface. Curr Opin Environ Sustain 14:232-8.

Gutierrez NL, Hilborn R, Defeo O. 2011. Leadership, social capital and incentives promote successful fisheries. Nature 470:386-9.

Halpern BS, Walbridge S, Selkoe KA, Kappel CV, Micheli F, D'Agrosa C, Bruno JF, Casey KS, Ebert C, Fox HE, Fujita R, Heinemann D, Lenihan HS, Madin EMP, Perry MT, Selig ER, Spalding M, Steneck R, Watson R. 2008. A global map of human impact on marine ecosystems. Science 319:948-52.

Hare S, Mantua N. 2000. Empirical evidence for North Pacific regime shift in 1977 and 1989. Prog Oceanogr 47:103-45.

Hoegh-Guldberg O, Bruno JF. 2010. The impact of climate change on the world's marine ecosystems. Science 328:1523-8.

Holling CS. 1973. Resilience and stability of ecological systems. Annu Rev Ecol Syst 4:1-23.

Homer-Dixon T, Walker B, Biggs R, CrÈpin A-S, Folke C, Lambin EF, Peterson GD, Rockström J, Scheffer M, Steffen W, Troell M. 2015. Synchronous failure: the emerging causal architecture of global crisis. Ecol Soc 20:6.

Howarth RW, Marino R. 2006. Nitrogen as the limiting nutrient for eutrophication in coastal marine ecosystems: Evolving views over three decades. Limnol Oceanogr 51:364-76.

Hughes TP, Bellwood DR, Folke C, Steneck RS, Wilson J. 2005. New paradigms for supporting the resilience of marine ecosystems. Trends Ecol Evol 20:380-6.

Jackson JBC, Kirby MX, Berger WH, Bjorndal KA, Botsford LW, Bourque BJ, Bradbury RH, Cooke R, Erlandson J, Estes JA, Hughes TP, Kidwell S, Lange CB, Lenihan HS, Pandolfi JM, Peterson CH, Steneck RS, Tegner MJ, Warner RR. 2001. Historical overfishing and the recent collapse of coastal ecosystems. Science 293:629-37.

Jacquet J, Hocevar J, Lai S, Majluf P, Pelletier N, Pitcher T, Sala E, Sumaila R, Pauly D. 2010. Conserving wild fish in a sea of market-based efforts. Oryx 44:45-56.

Keeling RF, Körtzinger A, Gruber N. 2010. Ocean deoxygenation in a warming world. Annu Rev Marine Sci 2:199-229.

Lade SJ, Niiranen S, Hentati-Sundberg J, Blenckner T, Boonstra WJ, Orach K, Quaas MF, Österblom H, Schlüter M. 2015. An empirical model of the Baltic Sea reveals the importance of social dynamics for ecological regime shifts. Proc Natl Acad Sci 112:11120-5.

Liu J, Hull V, Luo J, Yang W, Liu W, ViÒa A, Vogt C, Xu Z, Yang H, Zhang J, An L, Chen X, Li S, Ouyang Z, Xu W, Zhang H. 2015. Multiple telecouplings and their complex interrelationships. Ecol Soc 20:44.

Merino G, Barange M, Blanchard JL, Harle J, Holmes R, Allen I, Allison EH, Badjeck MC, Dulvy NK, Holt J, Jennings S, Mullon C, Rodwell LD. 2012. Can marine fisheries and aquaculture meet fish demand from a growing human population in a changing climate? Global Environ Change 22:795-806

Merrie A, Dunn DC, Metian M, Boustany AM, Takei Y, Elferink AO, Ota Y, Christensen V, Halpin PN, Österblom H. 2014. An ocean of surprises-trends in human use, unexpected dynamics and governance challenges in areas beyond national jurisdiction. Global Environ Change 27:19-31.

Norse EA, Brooke S, Cheung WWL, Clark MR, Ekeland I, Froese R, Gjerde KM, Haedrich RL, Heppell SS, Morato T, Morgan LE, Pauly D, Sumaila R, Watson R. 2012. Sustainability of deepsea fisheries. Marine Policy 36:307-20.

Norström AV, Nyström M, Jouffray J-B, Folke C, Graham NAJ, Moberg F, Olsson P, Williams GJ. 2016. Guiding coral reef futures in the Anthropocene. Front Ecol Environ (in press).

Nyström M, Graham NAJ, Lokrantz J, Norström AV. 2008. Capturing the cornerstones of coral reef resilience: linking theory to practice. Coral Reefs 27:795-809.

Nyström M, Norström AV, Blenckner T, de la Torre-Castro M, Eklöf JS, Folke C, Österblom H, Steneck RS, Thyresson M, Troell M. 2012. Confronting feedbacks of degraded marine ecosystems. Ecosystems 15:695-710.

Österblom H, Folke C. 2015. Globalization, marine regime shifts and the Soviet Union. Philos Trans R Soc B Biol Sci 370:20130278.

Österblom H, Jouffray J-B, Folke C, Crona B, Troell M, Merrie A, Rockström J. 2015. Transnational corporations as 'Keystone Actors' in marine ecosystems. PLoS ONE 10:e0127533.

Paine RT. 1969. A note on trophic complexity and community stability. Am Nat 103:91-3.

Pauly D, Belhabib D, Blomeyer R, Cheung WWWL, CisnerosMontemayor AM, Copeland D, Harper S, Lam VWY, Mai Y, Le Manach F, Österblom H, Mok KM, van der Meer L, Sanz A, Shon S, Sumaila UR, Swartz W, Watson R, Zhai Y, Zeller D. 2013. China's distant-water fisheries in the 21 st century. Fish Fish 15:474-88.

Perry RI, Ommer RE, Barange M, Jentoft S, Neis B, Sumaila UR. 2011. Marine social-ecological responses to environmental change and the impacts of globalization. Fish Fish 12:427-50.

Quinlan AE, Berbés-Blázquez M, Haider LJ, Peterson GD. 2015. Measuring and assessing resilience: broadening understanding through multiple disciplinary perspectives. J Appl Ecol 53: 677-687.

Rocha J, Yletyinen J, Biggs R, Blenckner T, Peterson G. 2015. Marine regime shifts: drivers and impacts on ecosystems services. Philos Trans R Soc B Biol Sci 370:20130273.

Rockström J, Steffen W, Noone K, Persson A, Chapin FS, Lambin EF, Lenton TM, Scheffer M, Folke C, Schellnhuber HJ, Nykvist B, de Wit CA, Hughes T, van der Leeuw S, Rodhe H, Sorlin S, Snyder PK, Costanza R, Svedin U, Falkenmark M, Karlberg L, Corell RW, Fabry VJ, Hansen J, Walker B, Liverman D, Richardson K, Crutzen P, Foley JA. 2009. A safe operating space for humanity. Nature 461:472-5.

Scheffer M, Carpenter S, Foley JA, Folke C, Walker B. 2001. Catastrophic shifts in ecosystems. Nature 413:591-6.

Scheffer M, Carpenter SR, Lenton TM, Bascompte J, Brock W, Dakos V, van de Koppel J, van de Leemput IA, Levin SA, van Nes EH, Pascual M, Vandermeer J. 2012. Anticipating critical transitions. Science 338:344-8.

Schultz L, Folke C, Österblom H, Olsson P. 2015. Adaptive governance, ecosystem management, and natural capital. Proc Natl Acad Sci 112:7369-74.

Troell M, Naylor RL, Metian M, Beveridge M, Tyedmers PH, Folke C, Arrow KJ, Barrett S, Crépin A-S, Ehrlich PR, Gren A, Kautsky N, Levin SA, Nyborg K, Österblom H, Polasky S, Scheffer M, Walker BH, Xepapadeas T, de Zeeuw A. 2014. 
Does aquaculture add resilience to the global food system? Proc Natl Acad Sci USA 111:13257-63.

Turner BLI, Clark WC, Kates RW, Richards JF, Mathews JT, Meyer WB. 1990. The Earth as transformed by human action: global and regional changes in the biosphere over the past 300 years. Cambridge: Cambridge University Press.

Walker B, Barrett S, Polasky S, Galaz V, Folke C, Engström G, Ackerman F, Arrow K, Carpenter S, Chopra K, Daily G, Ehr- lich P, Hughes T, Kautsky N, Levin S, Mäler K-G, Shogren J, Vincent J, Xepapadeas T, de Zeeuw A. 2009. Looming globalscale failures and missing institutions. Science 325:1345-6.

Young OR, Osherenko G, Ekstrom J, Crowder LB, Ogden J, Wilson JA, Day JC, Douvere F, Ehler CN, McLeod KL, Halpren BS, Peach R. 2007. Solving the crisis in ocean governance: place-based management of marine ecosystems. Environ Sci Policy Sustain Dev 49:20-32. 